\title{
Lack of improvement in sepsis care on the wards: results of four consecutive yearly point-prevalence studies in Wales
}

\section{Maja Kopczynska}

Salford Royal NHS Foundation Trust

Harry Unwin

Cardiff University

Richard Pugh

Betsi Cadwaladr University Health Board

\section{Ben Sharif}

Prince Charles Hospital

Thomas Chandy

Aneurin Bevan University Health Board

\section{Daniel Davies}

Swansea University

\section{Matthew Shield}

Swansea University

\section{David Purchase}

Cardiff University

Samuel Tilley

Cardiff University

Arwel Poacher

Cardiff and Vale University Health Board

Lewis Oliva

Cardiff University

\section{Sam Willis}

Hywel Dda University Health Board

Isabelle Ray

Cardiff University

John Hui

Aneurin Bevan University Health Board

\section{Bethan Payne}

Cardiff University 
Cardiff University

\section{Fi Andrew}

Cardiff University

Hei Priscilla Chan

Prince Charles Hospital

Jack Barrington

Cardiff University

Jay Hale

Cardiff University

Joanna Hawkins

Cardiff University

Jess Nicholas

Cardiff University

\section{Lara Wirt}

Cardiff University

\section{Lowri Thomas}

Cardiff University

\section{Megan Walker}

Wrexham Maelor Hospital

\section{Myat Pan}

Cardiff University

\section{Tallulah Ray}

Cardiff University

\section{Umair Asim}

Wrexham Maelor Hospital

\section{Victoria Maidman}

Cardiff University

\section{Zeid Atiyah}

Cardiff University

\section{Zain Nasser}

Cardiff University

\section{Zhao Tan}

West Suffolk NHS Foundation Trust

\section{Laura Tan}

Cardiff and Vale University Health Board

Tamas Szakmany ( $\square$ szakmanyt1@cardiff.ac.uk )

Cardiff University

\section{Welsh Digital Data Collection Platform Collaborators}




\section{Research Article}

Keywords: Sepsis, Sepsis bundle, Compliance, Mortality

Posted Date: April 3rd, 2021

DOl: https://doi.org/10.21203/rs.3.rs-379786/v1

License: (c) (i) This work is licensed under a Creative Commons Attribution 4.0 International License. Read Full License

Version of Record: A version of this preprint was published at Scientific Reports on August 10th, 2021. See the published version at https://doi.org/10.1038/s41598-021-95648-6. 


\section{Abstract}

Background: The 'Sepsis Six' bundle was promoted as a more deliverable tool outside of the critical care settings, but there is very little data available on the progress and change of sepsis care outside the critical care environment in the UK. Our aim was to compare the yearly prevalence, outcome and the Sepsis Six bundle compliance in patients at risk of mortality from sepsis in non-intensive care environments.

Methods: Patients with a National Early Warning Score (NEWS) of 3 or above and suspected or proven infection were enrolled into four yearly 24-hour point prevalence studies, carried out in fourteen hospitals across Wales from 2016-2019.

Results: Out of the 26,947 patients screened 1,651 fulfilled inclusion criteria and were recruited. The full 'Sepsis Six' care bundle was completed on 223 (14.0\%) occasions, with no significant difference between the years. On 190 (11.5\%) occasions none of the bundle elements were completed. There was no significant correlation between bundle element compliance, NEWS or year of study. One hundred and seventy $(10.7 \%)$ patients were seen by critical care outreach; the 'Sepsis Six' bundle was completed significantly more often in this group $(54 / 170,32.0 \%)$ than for patients who were not reviewed by critical care outreach $(168 / 1385,11.6 \% ; p<0.0001)$

Overall, 1349 patients (81.2\%) survived to 30 days with a mean survival time of 26.5 days $(95 \% \mathrm{Cl} 26.1$ 26.9) with no difference between each year of study. 90-day survival for years $2017-2019$ was $74.7 \%$, with no difference between the years. In multivariate regression we identified older age, heart failure, recent chemotherapy, higher frailty score and do not attempt cardiopulmonary resuscitation orders as significantly associated with increased 30-day mortality.

Conclusions: Our data suggests that despite efforts to increase sepsis awareness within the NHS, there is poor compliance with the sepsis care bundles and no change in the high mortality over the study period. Further research is needed to determine which time-sensitive ward-based interventions can reduce mortality in patients with sepsis and how can these results be embedded to routine clinical practice.

Trial registration: Defining Sepsis on the Wards ISRCTN 86502304 https://doi.org/10.1186/ISRCTN86502304 prospectively registered 09/05/2016

\section{Background}

Sepsis is defined as dysregulated host response to infection with sequential organ failure. It is a complex disorder and is associated with high mortality [1]. Despite increased awareness, sepsis remains a major challenge and economic burden to healthcare globally [2][3][4][5]. To improve patient mortality, sepsis requires early recognition and urgent treatment [6]. Previously much attention was dedicated to the identification and treatment of patients at risk of poor outcomes within intensive care units (ICU) [7][8]. 
However, it is now known that the majority of patients with sepsis present in the emergency department (ED) and on general wards, with associated high mortality[9][10][11].

Since the inception of the sepsis resuscitation bundle by the Surviving Sepsis Campaign (SSC) over a decade ago, completion rates have been reportedly low [12][13][14]. As the initial SSC bundle was heavily reliant on complex interventions, typically performed in a critical care environment, the 'Sepsis Six' bundle was promoted as a more deliverable tool outside of the critical care settings [15]. Although high-profile cases and systematic campaign from advocacy groups helped to increase awareness of the condition in the last decade, there is very little data available on the progress and change of sepsis care outside the critical care environment in the UK [15][16]. While the use of sepsis screening tools and the delivery of the 'Sepsis Six' bundle is now a key performance indicator in many institutions, external scrutiny of such initiatives is lacking [17][18]. The aim of our study was to examine the changes in care processes and outcomes over a four-year period, by utilising our yearly All Wales point-prevalence study on sepsis.

\section{Methods}

\section{Study design and participants}

We performed a secondary analysis on the patient populations recruited into four annual multi-centre 24hour point-prevalence studies conducted on the third Wednesday of October from 2016 to 2019. Ethical approval was granted by the South Wales Regional Ethics Committee (16/WA/0071, 15/04/2016) and patients or legal representatives gave written informed consent. The study was conducted accordance with relevant guidelines and regulations including the Declaration of Helsinki. The Defining Sepsis on the Wards project was prospectively registered with an international trial registry (ISRCTN86502304).

Patients were recruited from each of the 14 acute hospitals across Wales, all of which had 24-hour consultant cover in the ED and non-selective intake. We screened all patients presenting to the ED and on the general wards. Those with a National Early Warning Score (NEWS) of $\geq 3$ and proven or suspected infection were recruited. Patients under 18 and those cared for in critical care or mental health units were excluded.

We collected data from medical and nursing records using a specifically developed digital platform. Further description of the methodology and performance of this platform is outlined in previous publications [16][19][20][21][18][22][23]. We collected data on pre-admission patient characteristics, comorbidities, physiological and laboratory values, Dalhousie clinical frailty score, and management actions such as the completion of the 'Sepsis Six' bundle and involvement of critical care outreach. In 2016, we conducted follow-up data collection for our primary outcome of all-cause mortality at 30 days from enrolment. In subsequent years (2017-19) we conducted follow-up at 30 and 90 days.

Policy content: During the study period all of the participating hospitals were actively engaged in the Rapid Response to Acute Illness Learning Set (RRAILS) programme led by 1000 Lives Improvement. In 
escalation of patients to senior decision makers or for consideration of referral to critical care outreach. RRAILS promoted the use of standardised sepsis screening tool across the hospital since 2008 (see Supplementary Fig. 1).

\section{Statistical analysis}

Categorical variables are described as proportions and are compared using Chi square test. Continuous variables are described as median and interquartile range (IQR) and compared using Mann-Whitney U test. We plotted Kaplan-Meier survival curves and compared time-to-event data using log-rank testing. We estimated the respective hazard ratios (HRs) for the primary outcome within 30 days with a Cox proportional hazards model after adjustment for measured confounders. The model fit was assessed by the -2 log likelihood statistics and Chi-square test.

To increase sample size and to enable the inclusion of patients from all four study years, the primary analysis was performed on 30-day follow up results only. However, we also performed a subgroup analysis using the 90-day survival data using the results from the 2017-2019 studies. A two-tailed $p$ value $<0.05$ was considered statistically significant. All statistical tests were calculated using SPSS 25.0 (SPSS Inc., Chicago, IL). Data visualisation was performed in R (Version 1.2.1335) with packages: ggplot2 (v3.3.3), dplyr (v1.0.5), UpSetR (v1.4.0), ComplexHeatmap (v2.7.8.1000) and sunburstR (v2.1.5), utilising repositories from Github (hms-dbmi/UpSetR, jokergoo/ComplexHeatmap and timelyportfolio/sunburstR ).

\section{Results}

\section{Patient characteristics}

Over the four annual 24-hour point-prevalence study periods, we screened a total of 26,947 patients, of whom 1,651 met inclusion criteria and were subsequently recruited (Fig. 1).

Patient demographics and clinical characteristics for each year of study are shown in Table 1 . The median age (IQR [range]) of participants was 73 years (60-82 [18-103]) and more females 852 (51.6\%) than males 799 (48.4\%) were recruited. The median (IQR) frailty score was 5 (3-6). Age, gender, and frailty of participants did not vary between years (Table 1 ). 
Table 1

Demographics, clinical characteristics and survival of patients in each year of study. Values are median (IQR [range]), number (proportion) or mean $(95 \% \mathrm{Cl})$.

\begin{tabular}{|c|c|c|c|c|c|c|}
\hline \multicolumn{7}{|l|}{ Year } \\
\hline & 2016 & 2017 & 2018 & 2019 & All years & $P$ \\
\hline & $(n=380)$ & $(n=459)$ & $(n=413)$ & $(n=399)$ & $\begin{array}{l}(n= \\
1651)\end{array}$ & \\
\hline \multicolumn{7}{|l|}{$\begin{array}{l}\text { Patient } \\
\text { Demographics }\end{array}$} \\
\hline $\begin{array}{l}\text { Age: median } \\
\text { years }\end{array}$ & $\begin{array}{l}74 \text { (61- } \\
83 \text { [18- } \\
100])\end{array}$ & $\begin{array}{l}73(62-84 \\
[18-103])\end{array}$ & $\begin{array}{l}73(59-81 \\
[19-99])\end{array}$ & $\begin{array}{l}73(60-81 \\
[19-99])\end{array}$ & $\begin{array}{l}73(60- \\
82[18- \\
103])\end{array}$ & 0.41 \\
\hline Sex: male & $\begin{array}{l}180 \\
(47.4 \%)\end{array}$ & 231 (50.3\%) & $213(51.6 \%)$ & 175 (43.9\%) & $\begin{array}{l}799 \\
(51.6 \%)\end{array}$ & 0.12 \\
\hline $\begin{array}{l}\text { Survival to } 30 \\
\text { days }\end{array}$ & $\begin{array}{l}380 \\
(79.5 \%)\end{array}$ & 372 (81.0\%) & $343(83.1 \%)$ & 332 (83.2\%) & $\begin{array}{l}1349 \\
(81.7 \%)\end{array}$ & 0.38 \\
\hline $\begin{array}{l}\text { Survival: mean } \\
\text { days }\end{array}$ & $\begin{array}{l}25.5 \\
(24.5- \\
26.4)\end{array}$ & $\begin{array}{l}26.6(25.8- \\
27.3)\end{array}$ & $\begin{array}{l}26.8(26.0- \\
27.6)\end{array}$ & $\begin{array}{l}26.9(26.1- \\
27.6-)\end{array}$ & $\begin{array}{l}26.5 \\
(26.1- \\
26.9)\end{array}$ & 0.39 \\
\hline \multicolumn{7}{|l|}{$\begin{array}{l}\text { Clinical } \\
\text { characteristics }\end{array}$} \\
\hline COPD & $\begin{array}{l}112 \\
(30.9 \%)\end{array}$ & $118(26.2 \%)$ & 117 (30.1\%) & 135 (34.8\%) & $\begin{array}{l}482 \\
(30.3 \%)\end{array}$ & 0.06 \\
\hline Diabetes & $\begin{array}{l}75 \\
(20.7 \%)\end{array}$ & $98(21.8 \%)$ & 89 (22.9\%) & 71 (18.3\%) & $\begin{array}{l}333 \\
(20.9 \%)\end{array}$ & 0.44 \\
\hline $\begin{array}{l}\text { Drugs of } \\
\text { Abuse }\end{array}$ & $5(1.4 \%)$ & $8(1.8 \%)$ & $11(2.8 \%)$ & $7(1.8 \%)$ & $\begin{array}{l}31 \\
(1.9 \%)\end{array}$ & 0.51 \\
\hline Heart failure & $\begin{array}{l}45 \\
(12.4 \%)\end{array}$ & 49 (10.9\%) & $50(12.9 \%)$ & $39(10.1 \%)$ & $\begin{array}{l}183 \\
(11.5 \%)\end{array}$ & 0.58 \\
\hline Hypertension & $\begin{array}{l}107 \\
(29.5 \%)\end{array}$ & $165(36.7 \%)$ & $145(37.3 \%)$ & $140(36.1 \%)$ & $\begin{array}{l}557 \\
(35.0 \%)\end{array}$ & 0.09 \\
\hline $\begin{array}{l}\text { Ischemic heart } \\
\text { disease }\end{array}$ & $\begin{array}{l}63 \\
(17.4 \%)\end{array}$ & 82 (18.2\%) & 65 (16.7\%) & 67 (17.3\%) & $\begin{array}{l}277 \\
(17.4 \%)\end{array}$ & 0.95 \\
\hline Liver disease & $11(3.0 \%)$ & $13(2.9 \%)$ & $19(4.9 \%)$ & $16(4.1 \%)$ & $\begin{array}{l}59 \\
(3.7 \%)\end{array}$ & 0.39 \\
\hline Neuromuscular & $13(3.6 \%)$ & $16(3.6 \%)$ & $11(2.8 \%)$ & $12(3.1 \%)$ & $\begin{array}{l}52 \\
(3.3 \%)\end{array}$ & 0.92 \\
\hline $\begin{array}{l}\text { Recent } \\
\text { chemotherapy }\end{array}$ & $14(3.9 \%)$ & $21(4.7 \%)$ & $15(3.9 \%)$ & $24(6.2 \%)$ & $\begin{array}{l}74 \\
(4.7 \%)\end{array}$ & 0.37 \\
\hline
\end{tabular}




\begin{tabular}{|c|c|c|c|c|c|c|}
\hline \multicolumn{7}{|l|}{ Year } \\
\hline $\begin{array}{l}\text { Frailty score: } \\
\text { median* }\end{array}$ & $5(3-6)$ & $5(3-6)$ & $4(3-6)$ & $5(3-6)$ & $5(3-6)$ & 0.26 \\
\hline DNA-CPR & $\begin{array}{l}90 \\
(24.1 \%)\end{array}$ & $\begin{array}{l}123 \\
(27.5 \%)\end{array}$ & 92 (24.5\%) & 109 (27.9\%) & $414(26.1 \%)$ & 0.49 \\
\hline NEWS $\geq 6$ & $\begin{array}{l}115 \\
(30.3 \%)\end{array}$ & $\begin{array}{l}130 \\
(28.3 \%)\end{array}$ & $120(29.1 \%)$ & $121(30.3 \%)$ & $486(29.4 \%)$ & 0.90 \\
\hline
\end{tabular}

*Frailty score range was $0-9$ in all years

Data was missing for frailty score for a total of 64 patients; 7 in 2016, 12 in 2017, 37 in 2018 and 8 in 2019. Abbreviations; COPD, Chronic Obstructive Pulmonary Disease, DNA-CPR, Do Not Attempt Cardiopulmonary Resuscitation order, NEWS, National Early Warning Score, IQR, interquartile range, $95 \% \mathrm{Cl}, 95 \%$ confidence interval.

\section{Sepsis management}

Overall, 289 (18.2\%) patients were screened for sepsis using the 'All Wales sepsis screening tool'. The 'Sepsis Six' bundle was completed on 223 (14.0\%) occasions. There were no significant trends in completion rates of the screening tools between 2016 and 2019, nor in the proportion of patients seen by critical care outreach (Table 2).

Table 2

Screening and management of patients in each year of study. Values are number (proportion).

\begin{tabular}{|c|c|c|c|c|c|c|}
\hline \multicolumn{7}{|l|}{ Year } \\
\hline & 2016 & 2017 & 2018 & 2019 & & $P$ \\
\hline & $\begin{array}{l}(n= \\
373)\end{array}$ & $\begin{array}{l}(n= \\
446)\end{array}$ & $\begin{array}{l}(n= \\
380)\end{array}$ & $\begin{array}{l}(\mathrm{n}= \\
391)\end{array}$ & $\begin{array}{l}(n= \\
1590)\end{array}$ & \\
\hline Completed 'Sepsis Six' Bundle & $\begin{array}{l}44 \\
(11.8 \%)\end{array}$ & $\begin{array}{l}63 \\
(14.1 \%)\end{array}$ & $\begin{array}{l}58 \\
(15.3 \%)\end{array}$ & $\begin{array}{l}58 \\
(14.8 \%)\end{array}$ & $\begin{array}{l}223 \\
(14.0 \%)\end{array}$ & 0.53 \\
\hline Completed All Wales Screening tool & $\begin{array}{l}59 \\
(15.8 \%)\end{array}$ & $\begin{array}{l}100 \\
(22.4 \%)\end{array}$ & $\begin{array}{l}62 \\
(16.5 \%)\end{array}$ & $\begin{array}{l}68 \\
(17.4 \%)\end{array}$ & $\begin{array}{l}289 \\
(18.2 \%)\end{array}$ & 0.06 \\
\hline $\begin{array}{l}\text { Number of patients seen by Critical } \\
\text { Care Outreach }\end{array}$ & $\begin{array}{l}33 \\
(8.8 \%)\end{array}$ & $\begin{array}{l}56 \\
(12.6 \%)\end{array}$ & $\begin{array}{l}32 \\
(8.6 \%)\end{array}$ & $\begin{array}{l}49 \\
(12.5 \%)\end{array}$ & $\begin{array}{l}170 \\
(10.7 \%)\end{array}$ & 0.11 \\
\hline
\end{tabular}

Data was missing for; Completed All Wales Screening tool for 4 patients in 2018; Data was also missing for number of patients seen by critical care outreach for 6 patients in 2018. 
The completion of overall, as well as individual elements of the 'Sepsis Six' bundle over time is further presented in Fig. 2.

When examined individual bundle elements, lactate measurement and obtaining blood cultures improved over time; however all elements were completed well below $70 \%$ of occasions (Fig. 2). We found no differences between organisations in completing 'Sepsis Six' bundles (as displayed in Supplementary Fig. 2). Regardless of the number of bundle elements completed, we did not find any difference in the mortality across the years (Supplementary Fig. 3). No discernible trends or patterns were identified when we examined the completion of individual and combined bundle elements (Fig. 3 and further interactive visualisation in Supplementary Fig. 4 plus summary of most frequent combinations shown in Supplementary Fig. 5) or when this was plotted against the patients' NEWS across the study period (demonstrated in Supplementary Fig. 6).

Blood cultures were obtained from $632(46.0 \%)$ patients, of which $89(14.1 \%)$ were positive for growth. Sputum sampling had a substantially higher positivity rate (35.9\%). Other microbiology samples were infrequently collected (Table 3).

Table 3

Sepsis management - culture collection.

\begin{tabular}{|lll|}
\hline Culture & $\begin{array}{l}\text { Collected } \\
(\mathbf{n}=1651)\end{array}$ & Positive for growth \\
\hline Blood & $632(46.0 \%)$ & $89(14.1 \%)$ \\
\hline Sputum & $170(13.9 \%)$ & $61(35.9 \%)$ \\
\hline Urine & $455(33.4 \%)$ & $86(18.9 \%)$ \\
\hline Wound & $112(8.2 \%)$ & $54(48.2 \%)$ \\
\hline CSF & $8(0.6 \%)$ & $0(0 \%)$ \\
\hline
\end{tabular}

Abbreviation: CSF Cerebrospinal fluid

Antimicrobials were administered to 743 (64.3\%) patients. Piperacillin-tazobactam, followed by coamoxiclav and clarithromycin were the commonly used antibiotics used over the four-year period and are illustrated in Supplementary Fig. 7.

One hundred and seventy $(10.7 \%)$ patients were seen by critical care outreach; the 'Sepsis Six' bundle was completed significantly more often in this group $(54 / 170,32.0 \%)$ than for patients who were not reviewed by critical care outreach $(168 / 1385,11.6 \% ; p<0.0001)$. However, when plotted as a patient pathway these effects became less pronounced (illustrated in the river-plot in Supplementary Fig. 8). 
In planned sensitivity analysis we found that the percentage number of patients with NEWS 6 or above (overall $n=486,29.4 \%$ ) did not change significantly over the study period (Table 1 ). In this group, more patients had ceiling of care and DNA-CPR orders in place (19.7\% vs $9.5 \%, p<0.0001$ and $37.8 \%$ vs $21.2 \%$, $\mathrm{p}<0.0001$, respectively) compared to the less acutely unwell population. The completion of the 'Sepsis Six' bundle was significantly higher $(20.9 \%$ vs $11.1 \%, p<0.0001)$ but unchanged over the study period, as was the completion rate for individual bundle elements (shown in Supplementary Fig. 9).

\section{Survival analysis}

Overall, 1349 of 1651 patients (81.2\%) survived to 30 days with a mean survival time of 26.5 days (95\% $\mathrm{Cl}$ 26.1-26.9). We found no difference in patient survival at 30 days between each year of study (Table 1 and Fig. 4).

We observed significantly higher mortality in patients with NEWS 6 or above $(23.5 \%$ vs $16.1 \%, p<0.0001)$. Overall 90-day survival for years $2017-2019$ was $74.7 \%$ (949/1271). There was no difference in patient survival at 90 days between each year (see Kaplan-Meier curve in Supplementary Fig. 10).

\section{Risk factors of mortality}

On multivariate regression analysis, we identified older age, heart failure, recent chemotherapy, higher frailty score and do not attempt cardiopulmonary resuscitation (DNA-CPR) orders as significantly associated with increased mortality in patients with sepsis (Table 4). 
Table 4

Multivariate Cox regression analysis of the risk factors for mortality in sepsis patients. Values are Hazards ratio $(95 \% \mathrm{Cl})$.

\begin{tabular}{|lll|}
\hline Variables & Hazards Ratio (95\% Cl) & $P$ Value \\
\hline Demographics & & \\
\hline Age & $1.04(1.031 .05)$ & $<0.0001$ \\
\hline Sex & $1.30(0.96-1.74)$ & 0.09 \\
\hline Co-morbidities & & \\
\hline COPD & $0.95(0.70-1.30)$ & 0.77 \\
\hline Diabetes & $0.81(0.55-1.18)$ & 0.26 \\
\hline Drugs of Abuse & $0.46(0.06-3.37)$ & 0.45 \\
\hline HF & $1.50(1.03-2.20)$ & 0.04 \\
\hline HTN & $1.08(0.80-1.46)$ & 0.61 \\
\hline IHD & $0.87(0.60-1.27)$ & 0.48 \\
\hline Liver disease & $1.07(0.49-2.32)$ & 0.86 \\
\hline Neuromuscular & $1.33(0.61-2.89)$ & 0.47 \\
\hline Recent chemotherapy & $3.12(1.86-5.21)$ & $<0.0001$ \\
\hline Frailty Score & $1.17(1.05-1.30)$ & $<0.01$ \\
\hline DNA-CPR & $1.47(1.03-2.09)$ & 0.03 \\
\hline NEWS $\geq 6$ & $0.84(0.59-1.20)$ & 0.34 \\
\hline Management & & 0.10 \\
\hline Complete Sepsis Six Bundle & $0.67(0.42-1.08)$ & 0.60 \\
\hline All Wales Screening Tool & $0.86(0.58-1.29)$ & \\
\hline Seen by Critical Care Outreach & $1.13(0.72-1.77)$ & \\
\hline
\end{tabular}

Abbreviations; COPD chronic obstructive pulmonary disease, HF heart failure, HTN hypertension, IHD ischemic heart disease, DNA-CPR do not attempt cardiopulmonary resuscitation order. NEWS National Early Warning Score

\section{Discussion}


We identified that sepsis management in Wales (according to sepsis screening tool application and 'Sepsis Six' bundle compliance) has not altered over the four-year study period and that outcomes remain largely unchanged.

We found the demographic of the study population remained the same for each year, consisting of predominately frail and elderly patients with significant comorbidities. Approximately a third of the patients had a high NEWS and this group had higher likelihood of care limitations and DNA-CPR orders in place. Over the study period, there was no change in the short or medium-term mortality in the cohort, with approximately three out of four patients alive at 90 days. Our data opposes beliefs expressed that within the last decade the implementation of resuscitation bundles has led to better recognition of sepsis, in turn increasing the reported incidence of sepsis and reducing its apparent mortality [24][25][6]. Our observations are supported by recent analysis of studies identifying sepsis using direct clinical indicators of infection and organ dysfunction, suggesting that over the last decade the incidence and mortality of sepsis has in fact remained stable [26][27].

Our findings that older age and higher frailty score are both associated with increased risk of mortality from sepsis, within an elderly population with high comorbidity burden, emphasise the threat of sepsis to patients throughout our hospitals [3][28][29]. The observations that heart failure and previous chemotherapy are associated with higher mortality from sepsis, are not new and are supported by results from large international cohorts [11][30][31].

'Sepsis Six' bundle completion remained low with a mean of $14.0 \%$ over four years. The lack of improvement in completion of bundles probably underlines the significant problem of sepsis recognition outside of the ICU [32]. Our results support previously published UK and international data and highlight a significant concern in the real-world operationalising of response, which show significantly lower compliance in comparison to the sepsis performance measure (SEP-1) initiative or the resuscitation bundle promoted by the SCC [13][33]. Alarmingly, only one in five patients received the full bundle in a group with higher risk of deterioration, i.e. NEWS 6 or above, whilst only one out of ten patients received the full bundle in the lower acuity group, with no change over the four years. We found that patients who were reviewed by critical care outreach were more often treated with the full 'Sepsis Six' bundle and had antibiotics administered. This result is in line with previous experiences, where introduction of a dedicated team has improved compliance with the bundle [34]. Whilst our study did not find any association between critical care outreach involvement and mortality, it is possible that illness severity is a confounding factor here.

Our results point towards system failure to respond to sepsis as a medical emergency and highlight the need for policy change in the Welsh NHS in response to sepsis. The implementation of care bundles have been shown to have significant institutional barriers, which are unlikely to be overcome by the traditional plan-do-study-act quality improvement cycles [35][36]. Importantly, neither the 'Sepsis Six' bundle, nor the SEP-1 bundle has been tested in a robust randomised controlled trial (RCT) and their perceived effertivenecc hac heen deriver frnm nhcervational before and after studies with high risk of bias [37]. We Loading [MathJax]/jax/output/CommonHTML/jax.js

Page $12 / 23$ 
believe, based on the individual bundle element compliance figures, that our data may show the presence of clinical equipoise for an RCT to test whether a bundle approach indeed improves outcomes compared to the current apparent standard care of administering supplemental oxygen and antibiotics to the majority of the patients with NEWS above 6. Adaptive platform trials have been shown to be an effective, and efficient approach, and the recently funded Sepsis Trials in Critical Care (SEPTIC) platform (NIHR $17 / 136 / 02$ ) is paving the way for this approach. These novel infrastructures have been demonstrated to create 'learning health care systems' which provide more efficient knowledge generation by utilising a simple and purposeful data system architecture with transparent quality metrics, integrated into clinical, academic and commissioning structures [38].

Prime of examples are the RECOVERY and REMAP-CAP trials, which have been developed and embedded in different healthcare systems, with strong leadership during the last year in the COVID-19 pandemic [39] [40]. The RECOVERY programme in the UK NHS prioritises treatment options strategically, building on existing strengths and priorities whilst providing training systems, bringing significant advances to our care for patients suffering from viral sepsis both on the wards and in the critical care setting [41][42]. The success of this approach demonstrates the feasibility and the potential of rapid knowledge transfer from the use of adaptive trials in the comparative settings, especially during this pandemic era [42][43][44]. Considering the successes of the integrated Learning Healthcare System approaches and the significant evidence gap in the ward based sepsis care demonstrated in our study, we propose, that a similar platform trial is necessary to delineate which timely, ward-based interventions can reduce mortality in patients with sepsis at the highest risk of adverse outcomes [43][45].

There are certain limitations to our study. The dataset collected was a compromise between an exhaustive list of clinical and laboratory parameters and being small enough to maintain data reliability. The data collection was performed by medical students at various levels of their training, introducing potential bias. To counter this, robust online and in-person training was cascaded, and we ensured that medical student hospital leads in subsequent years had participated as data collectors [16][20][21]. We have also maintained the core clinical leadership of the group throughout the study. We have only collected longer-term outcome data and cause of death on a subset of patients and our long-term followup data is yet to be linked with the Welsh Secure Anonymous Information Linkage (SAIL) databank [29] [46]. The true human cost of sepsis in terms of re-hospitalisation and patient reported outcomes cannot be estimated from our results. Although one of the largest in-depth sepsis studies in the UK, the samplesize of Wales is relatively small and may not be generalisable. However, we could not see any differences in sepsis incidence or outcomes based on geographical area, hospital status or size and we ensured that all acute hospitals in Wales participated in each year of the study [16] [20][21]. Similarly, we have not seen any change in the number of patients reviewed by critical care outreach over the years. As critical care outreach and medical emergency team provision has been highly variable in Wales, it is possible that our sample was not representative [34]. The point-prevalence design might have resulted in spuriously low compliance measured with the completion of the 'Sepsis Six' bundle especially, that in March 2017 the NHS Wales Delivery Framework introduced the mandatory monthly reporting of compliance with 'Sepsis Loading [MathJax]/jax/output/CommonHTML/jax.js his mandatory reporting, there is no publicly available data 
on this metric in within the Welsh NHS. Moreover, our study has been widely advertised in the participating hospitals in all years to ensure uptake and our results have been consistent across the study period.

\section{Conclusions}

In summary, our data suggests that despite efforts to increase sepsis awareness within the NHS, there is poor compliance with the sepsis care bundles and no change in outcome over the study period. Our results highlight the ongoing need for RCTs to determine which time-sensitive ward-based interventions can reduce mortality in patients with highest risk of death and should be considered in the future to help to improve compliance with the sepsis treatment bundles.

\section{Declarations}

\section{Ethical Approval and consent to participate}

Ethical approval was granted by the South Wales Regional Ethics Committee (16/WA/0071, 15/04/2016) and patients or legal representatives gave written informed consent.

\section{Consent for publication}

Not applicable

\section{Availability of data and materials}

The datasets used and/or analysed during the current study are available from the corresponding author on reasonable request

Competing interests:

The authors declare that they have no competing interests.

\section{Funding}

This work was supported by the Fiona Elizabeth Agnew Trust and the Welsh Intensive Care Society, and they had no access to the data and no role in study design, conduct, analysis or drafting this report.

\section{Authors' contributions}

Conceptualization, MK, BS, TSz; formal analysis, MK, TSz; investigation, MK, HU, BS, RJP, TC, DD, MS, DP, ST, AP, LO, SW, IR, JNCH, BP, EW, FA, HMPC, JB, JH, JH, JN, LW, LHT, MW, PM, TR, U HA, VM, ZA, ZN, ZXTan, TSz; methodology, MK, HU, BS, TSz; project administration, MK, HU, BS, TSz; resources, TSz; supervision, TSz; visualization, MK, LJPT; writing - original draft, MK, HU, TSz; writing - review \& editing, Ill autharn All autharn mand and annmenad the final manuscript. 


\section{Acknowledgements}

The Authors would like to acknowledge the help of the Critical Care Outreach teams of the participating hospitals. The full list of collaborators is provided under the Welsh Digital Data Collection Platform Collaborators.

\section{Welsh Digital Data Collection Platform Collaborators}

A. Ariff, A. A. Collins, A. Adeleye, A. Almazeedi, A. Arunthavarajah, A. Ashaye, A. Ayob, A. Bilal, A. Boam, A. Burden, A. Campbell, A. Cawthra, A. Chrysostomou, A. Clack, A. Coleclough, A. Cooper, A. Cross, A.

Dandawate, A. Desai, A. Dhadda, A. Dickinson, A. Donnir, A. El-badawey, A. Evans, A. Fadlalla, A. Forrester, A. G. Mounce, A. Gilfedder, A. Gordon, A. Handley, A. Harris, A. Heal, A. Hodgson, A. Hook, A. Hughes, A. Khan, A. Kiran, A. Kurani, A. MacNaught, A. mahdi, A. Mcforrester, A. Mounce, A. Mukit, A. Niina, A. Noble, A. Norbee, A. O'Donnell, A. Owen, A. Paranjape, A. Prideaux, A. Qarout, A. Quy, A. Ramjeeawon, A. Redman, A. Rela, A. Robertson, A. Rogers, A. Sharma, A. Shipley, A. Stoddart, A. Sweeney, A. Taufik, A. Tayler, A. Tee, A. Urazbayeva, A. Urquhart, A. W. Z. Yeo, A. Waller, A. Zulkefli, B. Atkins, B. Bowyer, B. C. Walker B. Cunningham-Walker, B. Davies, B. Ellis, B. Hughes, B. James, B. Markall, B. Ponting, B. Soo, B. Tanner, C. Atkins, C. Battle, C. Brown, C. C. Y. Shean, C. Chantrill, C. Collins, C. Durie, C. Garbutt, C. Gilbert, C. Green, C. Hall, C. Houghton, C. James, C. Johnston, C. Lambirnudi, C. Lee, C. Littler, C. Maden, C. McKeown, C. Miles, C. Mykura, C. Ong, C. Pickwick, C. Roberts, C. Russell, C. Salmon, C. Scott, C. Smith, C. Spooner, C. Subbe, C. V. Vanderpump C. Zeicu, D. C. Hathaway, D. E. Samuel, D. Fellows, D. Hanna, D. Lawson, D. Li, D. Lis, D. Manning, D. Smith, D. Soppitt, D. Thomas, D. Usman, D. Zhao, E. A. Dillon, E. Adcock, E. Ang, E. Baker, E. Baxendale, E. Bisson, E. Boggon, E. Brittain, E. Cochrane, E. Davies, E. Eccles, E. Evans, E. Field, E. Haines, E. Hannay, E. Hartley, E. Higgins, E. Hodges, E. Howard, E. Hubbard, E. Ifan, E. Ireland, E. Kirby, E. Lambert, E. Mc Keag E. Murphy, E. Nelson-Rowe, E. Onyango, E. Rowe, E. Shore, E. Sparey, E. Sykes, E. Taylor, E. Twohey, E. Walker, E. Walters, E. Wickens, E. Withers, E. Wood, E. Yildirim, F. A. St John, F. Bee, F. Bennett, F. Davis, F. H. Mackey, F. Hussain, F. Lavric, F. Lock, F. Mitchell, F. S. John, G. Ashton, G. Covell, G. Donowho, G. Ellis, G. Gitau, G. Lacey, G. Lawerece, G. Lawrence, G. Logue, G. Parry, G. Ravishangar, G. St Pier, H. Atkinson, H. Beard, H. Beetham, H. Beresford, H. Brunnock, H. Burton, H. C. Sylvester, H. Dawson, H. E. V. Maine, H. G. von der Pahlen, H. Garrard, H. Griffiths, H. Hussain, H. J. Lim, H. Jones, H. Khan, H. M. Ali, H. Metezai, H. Penney, H. Preston, H. Reed, H. Rhys-Ellis, H. Rossiter, H. S. Bhachoo, H. Seymour, H. Shayan-Arani, H. Smith, H. Sprague, H. Waring, H. Whillis, H. Williams, H. Y. V. Pak, I. A. Silva, I. Alkurd, I. Bridges, I. Britton, I. Corrin, I. Hay, I. Irwin, I. Jones, I. Laid, I. Otahal, I. Patterson, I. Sutherland, I. Talbot, J. Abreu, J. Acheampong, J. Boss, J. Brown, J. Carter, J. Cochrane, J. Cutler, J. Davies, J. Davis, J. E. Hall, J. Edwards, J. Evans, J. Foulkes, J. Gee, J. Guilford, J. Inns, J. John, J. Joseph-Gubral, J. Kew, J. L. Kent, J. Lynch, J. McFadyen, J. McKenna, J. O'Hanlon, J. Pearce, J. Pitt, J. R. Gowar J. R. Gowar, J. Randall, J. Robbins, J. S. Smith, J. Scriven, J. Sharma, J. Smith, J. Tagg, J. Tan, J. Vautrey, J. Watts, J. Webber, J. Webster, J. Wellington, J. Whitaker, K. Armstrong, K. Asjadi, K. Bashir, K. Carnegie, K. Crisp, K. Godfray, K. Khan, K. Kwan, K. McGillian, K. Mitsaki, K. Moss, K. Osman, K. Pandit, K. Parmar, K. Pinto, K. Powell, K. Ramesh, K. Robertson, K. Shergill, K. Wang, L. Adcock, L. Allen, L. Banerjee, L. Bausor, L. Cook, L. D'Souza, . Hodges, L. J. Davis, L. Jones, L. Macchiavello, L. Maw, L. 
McCarthy, L. Money, L. Morgan, L. Murphy, L. Nessa, L. Pike, L. Polchar, L. Sanders-Crook, L. Sharma, L. Tucker, L. W. Davies L. W. Davies, L. Webber, L. Wilcock, L. Williams, L. Xin, M. Almulaifi, M. Alsaeed, M. Ashman, M. Bradley, M. Broderick, M. Cox, M. Cuthbert, M. Cynan, M. Davies, M. E. Clark, M. Gruber, M. Hobrok, M. Jeyanthi, M. Karim, M. Keast, M. L. Ashman, M. Lee, M. Mazur, M. Mo, M. Nalbanti, M. Nalmpanti, M. Perry, M. Selby, M. Sethi, M. Sivananthan, M. Stone, M. T. Pierce, M. Taylor, M. Thomas, M. Timlin, M. Vreugdenhil, M. Warlow, M. Wu, M. Y. Amjad, M. Zafar, M. Zimmerman, N. A. B. Maliki, N. Allybocus, N. Dennehey, N. Doyle, N. Farzana, N. Foley, N. H. A. Hanif, N. Hoyle, N. Jarrett, N. Jones, N. Kaur, N. Logier, N. Malik, N. McSwiney, N. Mtunzi, N. N. Tantirige, N. Nadeem, N. Nandra, N. Poobalan, N. Poolworaluk, N. S. N. Azis, N. Savill, N. Seedat, N. Spencer, N. Syed, N. Vadivale, N. Vignarajah, N.

Youssef, N. Zulkifili, N. Zulkifli, N. West, O. Amatotsero, O. Cranage, O. Eghosa, O. Emanuel, O. Godsafe, O. Kyriakides, O. Marei, O. Minik, O. Moore, O. Richards, O. Ross, P. Baby, P. Benc, P. Havalda, P. McNulty, P. Moghbel, P. Morgan, P. Thara, Q. Z. Siah, R. B. Ross, R. Betts, R. C. E. Alaoui, R. Caradine, R. Church, R. Creamer, R. Desai, R. Edwards, R. Evans, R. G. Roberts, R. Gwyn, R. Howcroft, R. J. H. Sinnerton, R. Jones, R. Jordache, R. Joseph, R. Keeling, R. Kerrigan, R. Khanam, R. Long, R. Lundin, R. Lyons, R. Mallinson, R. Morgan, R. Otto, R. Paddock, R. Parsonson, R. Patel, R. Phillips, R. Price, R. Self, R. Sinnerton, R. T. Jones, R. Vindla, R. Walford, R. Watson, R.Ludin S. A. Thomas, S. Ahmed, S. Balachandran, S. Booth, S. Chun, S. Cleaver, S. Davies, S. DeFriend, S. Ganesananthan, S. H. Meehan, S. Hardie, S. Ireland, S. Jones, S. Kinsman, S. Kulikouskaya, S. L. Yao, S. Lim, S. Narine, S. Nightingale, S. O'Connor, S. P. Jones, S. Parida, S. Patel, S. Pengelly, S. Seet, S. Stovold, S. Szoke, S. T. N. Cheng, S. T. Seal S. Tanatova, S. Thanthilla, S. Venning, S. Vickery, S. W. Y. Ng, S. Y. Heng, S. Y. Kwak, T. Burgher, T. Burnett, T Canning, T. Chamberlain, T. David, T. Downs, T. G. Ng, T. Grother, T. Haddock, T. Hughes, T. J. Jones, T. Jones, T. Lau, T. Liddell-Lowe, T. Pontin, T. R. Gregg, T. Roberts, T. Spence, T. Telford, T. Thomas, T. V. Vadiveloo, T. X. M. Ly, T. Y. T. Shan, T. Yang, U. Ali, U. Asim, V. Hamlyn, V. Inpahas, V. Unadkat, V. Y. Y. Ling, W. B. W. Azzlan, W. Groblewski, W. J. Kozuch, W. L. Chia, Y. Abdelrazik, Y. Cheema, Y. H. L. Lau, Y. Hafouda, Y. K. Ying, Y. Y. Lim, Z. A. Hinchcliffe, Z. Black, Z. Liman, Z. McCarroll, Z. Teh, Z. X. Lee, H. Unwin, M. Kopczynska, R.J. Pugh, B. Sharif, T. Chandy, D. Davies, M. Shield, D. Purchase, S. Tilley, A. Poacher, L. Oliva, S. Willis, I. Ray, J.N.C. Hui, B. Payne, E. Wardle, F. Andrew, H.M.P. Chan, J. Barrington, J. Hale, J. Hawkins, J. Nicholas, L. Wirt, L.H. Thomas, M. Walker, P. Myat, T. Ray, U. H.Asim, V. Maidman, Z. Atiyah, Z. Nasser, Z. X. Tan., L. J. P. Tan, T. Szakmany

\section{References}

1. Re inhart K, Daniels R, Kissoon N, Machado FR, Schachter RD, Finfer S. Recognizing Sepsis as a Global Health Priority - A WHO Resolution. N Engl J Med. 2017;377:414-7.

2. Fleischmann C, Scherag A, Adhikari NKJ, Hartog CS, Tsaganos T, Schlattmann P, et al. Assessment of Global Incidence and Mortality of Hospital-treated Sepsis. Current Estimates and Limitations. Am J Respir Crit Care Med. 2016;193:259-72.

3. Buchman TG, Simpson SQ, Sciarretta KL, Finne KP, Sowers N, Collier M, et al. Sepsis Among Medicare Beneficiaries: 1. The Burdens of Sepsis, 2012-2018. Crit Care Med. 2020;48:276-88. 
4. Rudd KE, Johnson SC, Agesa KM, Shackelford KA, Tsoi D, Kievlan DR, et al. Global, regional, and national sepsis incidence and mortality, 1990-2017: analysis for the Global Burden of Disease Study. The Lancet. 2020;395:200-11.

5. Buchman TG, Simpson SQ, Sciarretta KL, Finne KP, Sowers N, Collier M, et al. Sepsis Among Medicare Beneficiaries: 3. The Methods, Models, and Forecasts of Sepsis, 2012-2018. Crit Care Med. 2020;48:302-18.

6. Seymour CW, Gesten F, Prescott HC, Friedrich ME, Iwashyna TJ, Phillips GS, et al. Time to Treatment and Mortality during Mandated Emergency Care for Sepsis. N Engl J Med. 2017;376:2235-44.

7. Bone RC, Balk RA, Cerra FB, Dellinger RP, Fein AM, Knaus WA, et al. Definitions for sepsis and organ failure and guidelines for the use of innovative therapies in sepsis. The ACCP/SCCM Consensus Conference Committee. American College of Chest Physicians/Society of Critical Care Medicine. Chest. 1992;101:1644-55.

8. Singer M, Deutschman CS, Seymour CW, Shankar-Hari M, Annane D, Bauer M, et al. The Third International Consensus Definitions for Sepsis and Septic Shock (Sepsis-3). JAMA 2016;315:80110.

9. Mearelli F, Orso D, Fiotti N, Altamura N, Breglia A, De Nardo M, et al. Sepsis outside intensive care unit: the other side of the coin. Infection. 2014;43:1-11.

10. Esteban A, Frutos-Vivar F, Ferguson ND, Peñuelas O, Lorente JA, Gordo F, et al. Sepsis incidence and outcome: contrasting the intensive care unit with the hospital ward. Crit Care Med. 2007;35:1284-9.

11. Buchman TG, Simpson SQ, Sciarretta KL, Finne KP, Sowers N, Collier M, et al. Sepsis Among Medicare Beneficiaries: 2. The Trajectories of Sepsis, 2012-2018. Crit Care Med. 2020;48:289-301.

12. Dellinger RP, Levy MM, Rhodes A, Annane D, Gerlach H, Opal SM, et al. Surviving Sepsis Campaign: International Guidelines for Management of Severe Sepsis and Septic Shock, 2012. Intensive Care Med. 2013;39:165-228.

13. Baghdadi JD, Brook RH, Uslan DZ, Needleman J, Bell DS, Cunningham WE, et al. Association of a Care Bundle for Early Sepsis Management With Mortality Among Patients With Hospital-Onset or Community-Onset Sepsis. JAMA Intern Med. 2020;180:707-16.

14. Rhodes A, Phillips G, Beale R, Cecconi M, Chiche JD, De Backer D, et al. The Surviving Sepsis Campaign bundles and outcome: results from the International Multicentre Prevalence Study on Sepsis (the IMPreSS study). Intensive Care Med. 2015;41:1620-8.

15. Daniels R, Nutbeam T, McNamara G, Galvin C. The sepsis six and the severe sepsis resuscitation bundle: a prospective observational cohort study. Emerg Med J 2011;28:507-12.

16. Szakmany T, Pugh R, Kopczynska M, Lundin RM, Sharif B, Morgan P, et al. Defining sepsis on the wards: results of a multi-centre point-prevalence study comparing two sepsis definitions. Anaesthesia. 2018;73:195-204.

17. NHSWalesDeliveryFramework2017_18.pdf [Internet]. [cited 2021 Mar 7]. Available from: https://ruralhealthandcare.wales/wp-

Loading [MathJax]/jax/output/CommonHTML/jax.js eliveryFramework2017_18.pdf 
18. Frankling C, Patel J, Sharif B, Melody T, Yeung J, Gao F, et al. A Snapshot of Compliance with the Sepsis Six Care Bundle in Two Acute Hospitals in the West Midlands, UK. Indian J Crit Care Med 2019;23:310-5.

19. Sharif B, Lundin RM, Morgan P, Hall JE, Dhadda A, Mann C, et al. Developing a digital data collection platform to measure the prevalence of sepsis in Wales. J Am Med Inform Assoc 2016;23:1185-9.

20. Kopczynska M, Sharif B, Cleaver S, Spencer N, Kurani A, Lee C, et al. Red-flag sepsis and SOFA identifies different patient population at risk of sepsis-related deaths on the general ward. Medicine (Baltimore). 2018;97:e13238.

21. Kopczynska M, Sharif B, Unwin H, Lynch J, Forrester A, Zeicu C, et al. Real World Patterns of Antimicrobial Use and Microbiology Investigations in Patients with Sepsis outside the Critical Care Unit: Secondary Analysis of Three Nation-Wide Point Prevalence Studies. J Clin Med. 2019;8:1337.

22. Wong AV, Arora N, Olusanya O, Sharif B, Lundin RM, Dhadda A, et al. Insertion rates and complications of central lines in the UK population: A pilot study. J Intensive Care Soc. 2018;19:1925.

23. Kopczynska M, Sharif B, Pugh R, Otahal I, Havalda P, Groblewski W, et al. Prevalence and Outcomes of Acute Hypoxaemic Respiratory Failure in Wales: The PANDORA-WALES Study. J Clin Med. 2020;9:3521.

24. Levy MM, Artigas A, Phillips GS, Rhodes A, Beale R, Osborn T, et al. Outcomes of the Surviving Sepsis Campaign in intensive care units in the USA and Europe: a prospective cohort study. Lancet Infect Dis. 2012;12:919-24.

25. Miller RR, Dong L, Nelson NC, Brown SM, Kuttler KG, Probst DR, et al. Multicenter implementation of a severe sepsis and septic shock treatment bundle. Am J Respir Crit Care Med. 2013;188:77-82.

26. Rhee C, Murphy MV, Li L, Platt R, Klompas M, Centers for Disease Control and Prevention Epicenters Program. Comparison of trends in sepsis incidence and coding using administrative claims versus objective clinical data. Clin Infect Dis 2015;60:88-95.

27. Rhee C, Dantes R, Epstein L, Murphy DJ, Seymour CW, Iwashyna TJ, et al. Incidence and Trends of Sepsis in US Hospitals Using Clinical vs Claims Data, 2009-2014. JAMA. 2017;318:1241.

28. Rhee C, Jones TM, Hamad Y, Pande A, Varon J, O'Brien C, et al. Prevalence, Underlying Causes, and Preventability of Sepsis-Associated Mortality in US Acute Care Hospitals. JAMA Netw Open. 2019;2:e187571.

29. Kopczynska M, Sharif B, Cleaver S, Spencer N, Kurani A, Lee C, et al. Sepsis-related deaths in the atrisk population on the wards: attributable fraction of mortality in a large point-prevalence study. BMC Res Notes. 2018;11:720.

30. Martin GS, Mannino DM, Moss M. The effect of age on the development and outcome of adult sepsis. Crit Care Med. 2006;34:15-21.

31. Knoop ST, Skrede S, Langeland N, Flaatten HK. Epidemiology and impact on all-cause mortality of sepsis in Norwegian hospitals: A national retrospective study. PloS One. 2017;12:e0187990-13. 
32. Yealy DM, Huang DT, Delaney A, Knight M, Randolph AG, Daniels $R$, et al. Recognizing and managing sepsis: what needs to be done? BMC Med. 2015;13:98.

33. Deis AS, Whiles BB, Brown AR, Satterwhite CL, Simpson SQ. Three-Hour Bundle Compliance and Outcomes in Patients With Undiagnosed Severe Sepsis. CHEST. 2018;153:39-45.

34. Burke J, Wood S, Hermon A, Szakmany T. Improving outcome of sepsis on the ward: introducing the "Sepsis Six" bundle. Nurs Crit Care. 2019;24:33-9.

35. Green SA, Bell D, Mays N. Identification of factors that support successful implementation of care bundles in the acute medical setting: a qualitative study. BMC Health Serv Res. 2017;17:120.

36. Smith DJ, Aitken LM. Use of a single parameter track and trigger chart and the perceived barriers and facilitators to escalation of a deteriorating ward patient: a mixed methods study. J Clin Nurs. 2016;25:175-85.

37. Wang J, Strich JR, Applefeld WN, Sun J, Cui X, Natanson C, et al. Driving blind: instituting SEP-1 without high quality outcomes data. J Thorac Dis 2020;12: doi:10.21037/jtd.2019.12.100

38. Angus DC, Alexander BM, Berry S, Buxton M, Lewis R, Paoloni M, et al. Adaptive platform trials: definition, design, conduct and reporting considerations. Nat Rev Drug Discov. 2019;18:797-807.

39. Huang DT, McVerry BJ, Horvat C, Adams PW, Berry S, Buxton M, et al. Implementation of the Randomized Embedded Multifactorial Adaptive Platform for COVID-19 (REMAP-COVID) trial in a US health system-lessons learned and recommendations. Trials. 2021;22:100.

40. Wilkinson E. RECOVERY trial: the UK covid-19 study resetting expectations for clinical trials. BMJ. 2020;369:m1626.

41. The RECOVERY Collaborative Group. Effect of Hydroxychloroquine in Hospitalized Patients with Covid-19. N Engl J Med. 2020;383:2030-40.

42. RECOVERY Collaborative Group. Dexamethasone in Hospitalized Patients with Covid-19. N Engl J Med. 2021;384:693-704.

43. Yusuf $\mathrm{S}$, Collins R, Peto R. Why do we need some large, simple randomized trials? Stat Med. 1984;3:409-20.

44. The REMAP-CAP Investigators. Interleukin-6 Receptor Antagonists in Critically III Patients with Covid19. N Engl J Med. 2021; doi:10.1056/NEJMoa2100433

45. Morain SR, Kass NE, Grossmann C. What allows a health care system to become a learning health care system: Results from interviews with health system leaders. Learn Health Syst. 2017;1:e10015.

46. Lyons RA, Jones KH, John G, Brooks CJ, Verplancke J-P, Ford DV, et al. The SAIL databank: linking multiple health and social care datasets. BMC Med Inform Decis Mak. 2009;9:3.

\section{Figures}




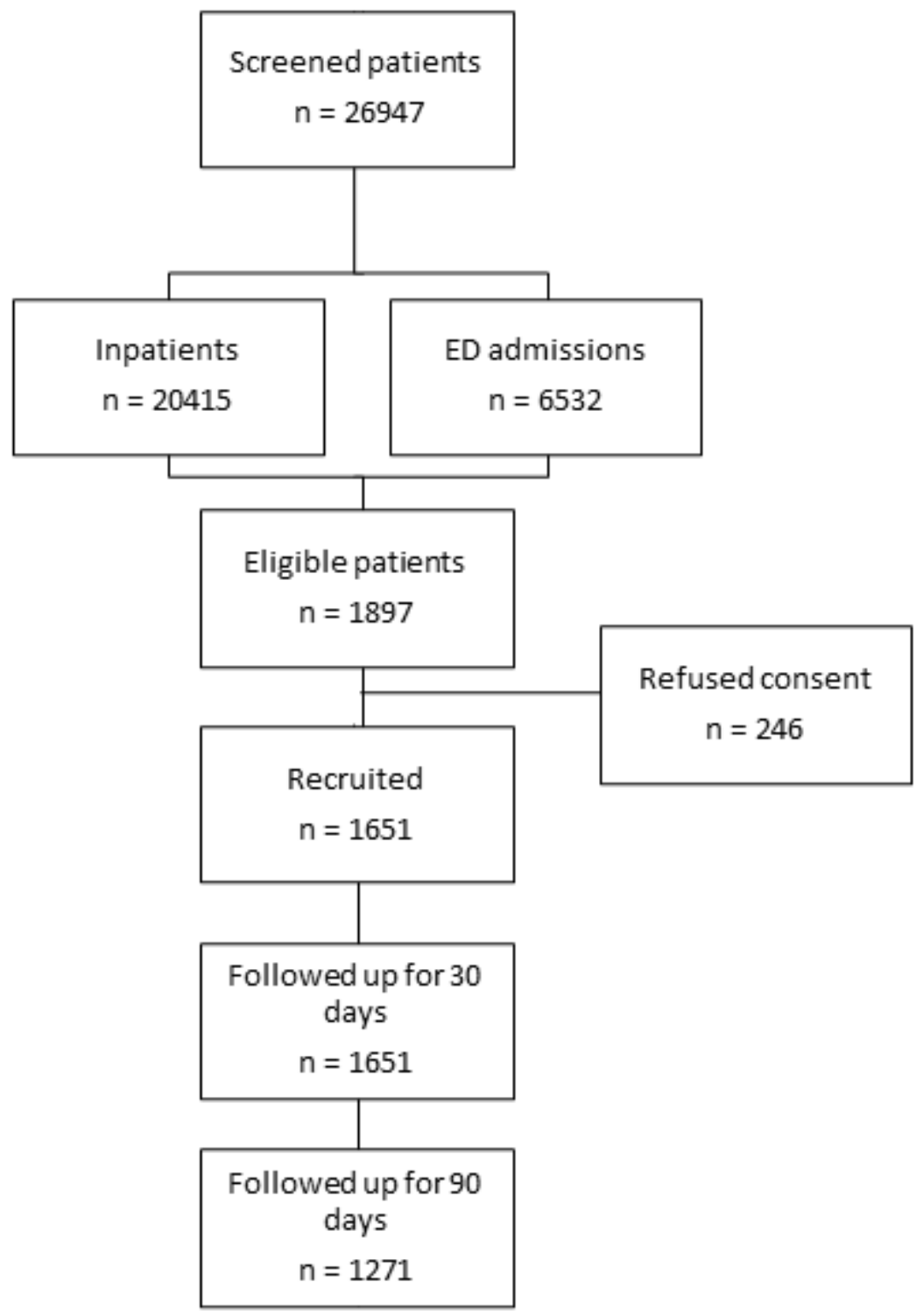

Figure 1

Study flow diagram and eventual study sample. ED; emergency department. 


\section{'Sepsis Six' Bundle Components - completion rate}

$80.0 \%$

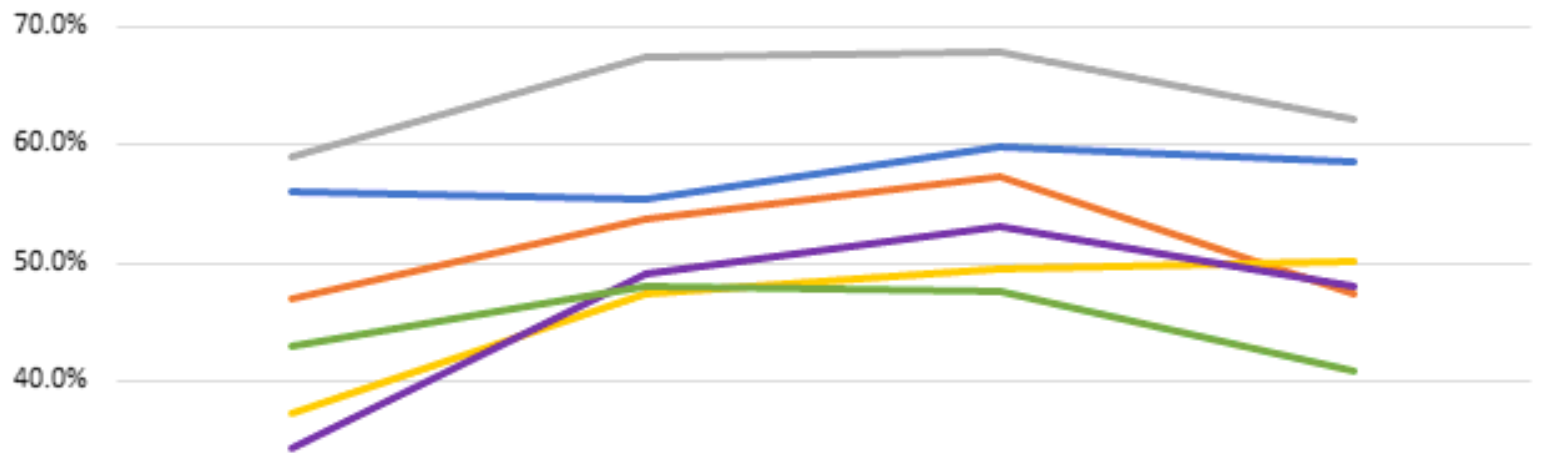

$30.0 \%$

- 02 administration

IV fluids

Antimicr obials

Blood cultures

Lactate

Urine output

_Complete Sepsis Six

$20.0 \%$

$10.0 \%$

$0.0 \%$

2016

2017

2018

2019

\section{Figure 2}

'Sepsis Six' bundle completion rates during the study period. Data is presented for overall (dark blue line) and individual bundle elements: 02 administration (blue line), IV fluids (orange line), antimicrobials (grey line), blood cultures (yellow line), lactate (purple line), urine output measurement (green line). 


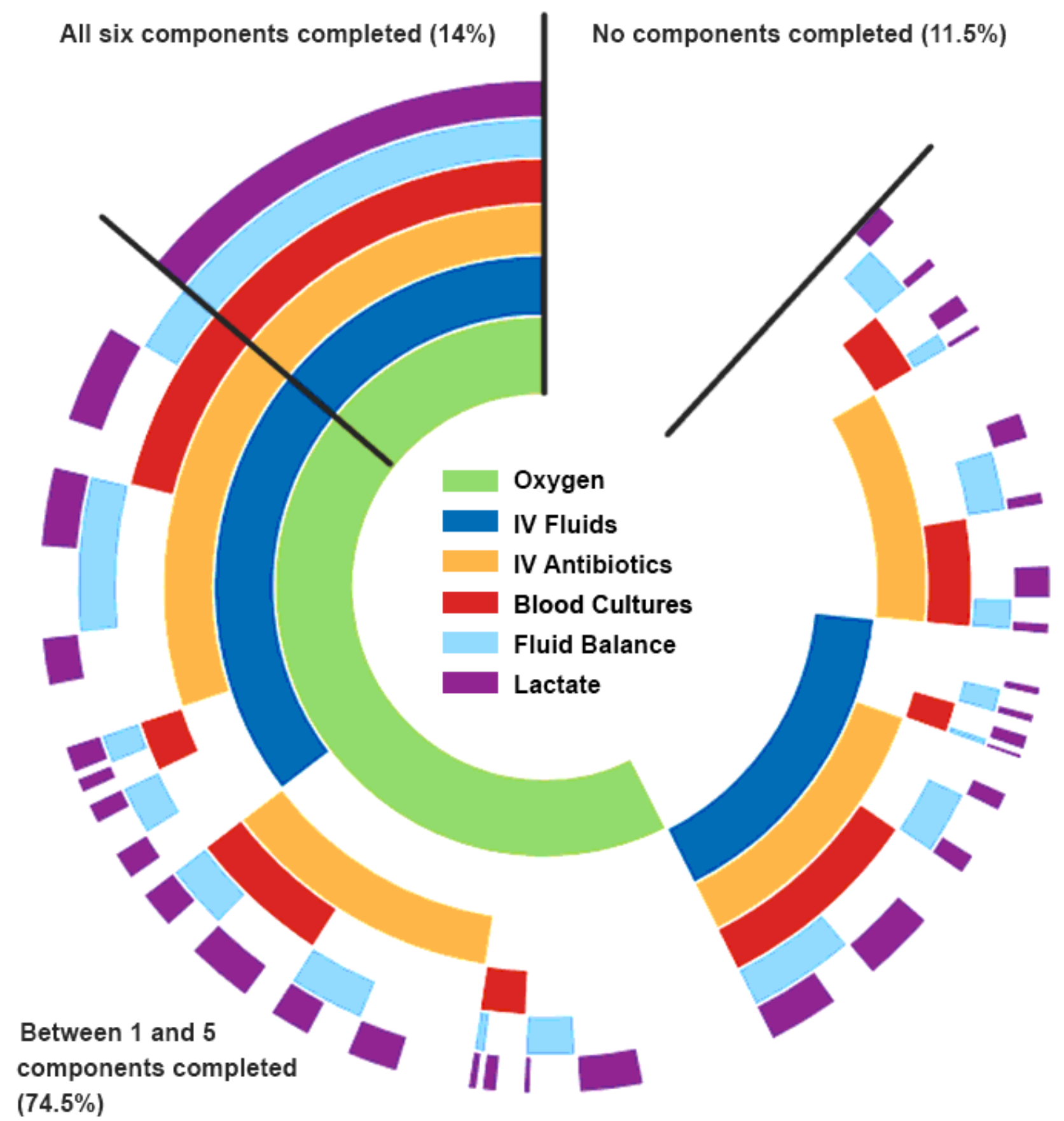

Figure 3

'Sepsis Six' bundle element completion rates A sunburst plot illustrating the frequency of completion of each component of the Sepsis Six bundle for the total events from 2016-2019 ( $n=1588$, with missing values removed). The coloured areas denote the Sepsis Six component has been completed, the grey areas denote where a component has not been completed. Working from the center, the frequency of each combination of Sepsis Six bundle components is illustrated. IV: intravenous. 


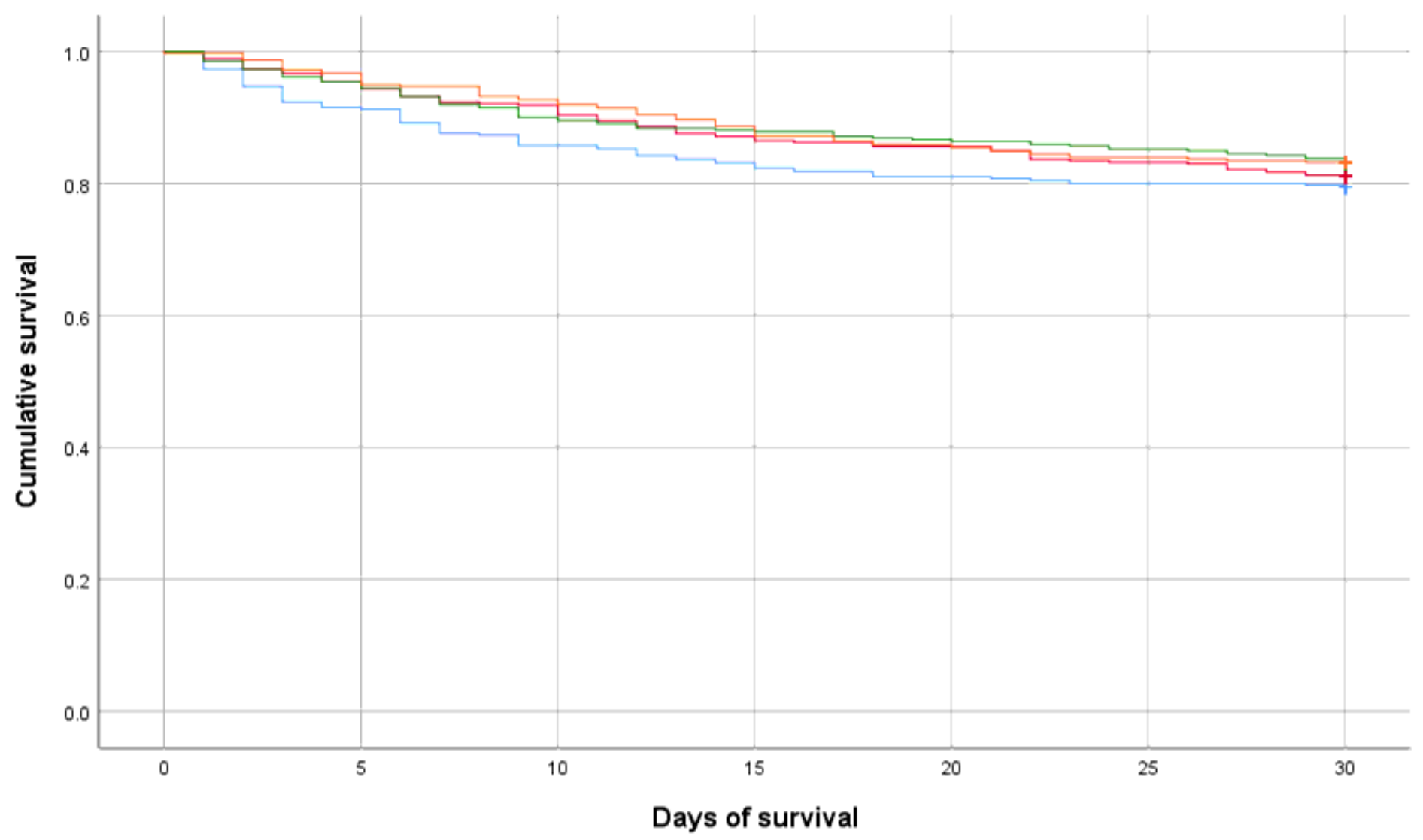

\section{Figure 4}

Survival difference of patients with sepsis presenting to emergency department or general wards in fourteen Welsh hospitals in the years; 2016 (blue line), 2017 (red line), 2018 (green line) and 2019 (orange line), $p=0.39$.

\section{Supplementary Files}

This is a list of supplementary files associated with this preprint. Click to download.

- PHWSepsisScreeningLeaflet11.pdf

- CCSupplementaryFigure2.tiff

- CCSupplementaryFigure3Sepsis6bundleperyearV2.tiff

- CCSupplementaryFigure4InteractivePlot.html

- CCSupplementaryFigure5upsetplotperc.png

- CCSupplementaryFigure6Sepsis6andNEWSV2.tiff

- CCSupplementaryFigure8.png

- newSupplementaryFigure9.tif

- newSupplementaryFigure10.tif 